\title{
Islandness and struggles over development: A Tasmanian case study
}

\author{
Elaine Stratford* \\ School of Geography and Environmental Studies, University of Tasmania, \\ Private Bag 78, Hobart TAS 7001, Australia
}

\begin{abstract}
This paper seeks to explore two propositions: that islands are constitutive of emotional geographies that may be described as islandness; and that islandness could be a key ontological resource among those who govern (on) islands, particularly where economic development activities generate deep-seated divisions. The paper also responds to two claims: one that localized studies are needed to augment the many that exist of 'globalization from above'; the other that island studies are marginal in geography in the same way that islands seem peripheral to continents. I address these matters with reference to research about major reforms to fiscal and environmental policy in Tasmania, Australia's only island state. There, deep divisions exist about the effects on community and place of various processes of economic globalization and ecological modernization, especially those involving resource-extractive industries such as forestry. Key proponents of the reform process were asked to reflect on how their work was informed by Tasmania's status as both a sub-national jurisdiction of Australia and an island; and were invited to ponder the State's political, economic and environmental position then and now. Interesting on its own terms as a study of political geographies at the microscale, the case also enables general conjecture about the capacity of islandness to generate spaces of rapprochement and craft political practices for agonistic ends. (C) 2007 Elsevier Ltd. All rights reserved.
\end{abstract}

Keywords: Islandness; Ontology; Agonism; Government; Sense of place; Tasmania

\section{Introduction}

This paper is premised on the idea that islandness is a complex expression of identity that attaches to places smaller than continents and surrounded entirely by water. These

* Tel.: +61 (0) 36226 2462; fax: +61 (0) 36226 2989; mobile: 0409956384.

E-mail address: elaine.stratford@utas.edu.au 
identifications include, but are not confined to, strong perceptions of island-self and mainlandother, as well as potent connections to island communities and environments. They embrace water, sky and land, flows and boundaries, edges and interiors, isolation and access (Clark, 2004; Deloughrey, 2004; Hache, 1998; Holm, 2002; Péron, 2004; Royle, 2001; Stratford, 2003). No less powerful than place-based identifications among plains or mountain or forest peoples, islandness might be described as a particular (and inevitably contingent) sense of being in place, although no inference is made here about that sense being necessarily harmonious.

In what follows, I do not enter into debates about what islands are, what categories they might include, what symbolic meaning they may have. I do not review contestations over the boundaries of island studies relative to other disciplines, nor comment on whether islands are more or less vulnerable or resilient to geopolitical, social, cultural and environmental upheavals. That has been done to great effect by others such as Godfrey Baldacchino (2006) and Peter Hay (2006). I do suggest that islandness may be described as an affect of particular land- and water-scapes, valued for their special qualities and deemed worthy of protection as such. As Hay (2006: 31) notes,

... islands - real islands, real geographical entities - attract affection, loyalty, identification. And what do you get when you take a bounded geographical entity and add an investment of human attachment, loyalty and meaning? You get the phenomenon known as 'place'. Islands are places - special places, paradigmatic places, topographies of meaning in which the qualities that construct place are dramatically distilled.

The thesis I seek to advance is that, among those who govern, an appreciation of the ontological power of islandness could aid the protection of island places from inappropriate economic development. The term 'inappropriate' may be variously defined; what matters here is that the suitability of development is often not decided by islanders, or may be determined by a handful of resident elites in ways that hide, ignore or fail to notice the importance of islandness for others. In this sense, the thesis reiterates larger and well-established ideas of belonging but, given the paucity of empirical work on such ideas as they pertain to islands, my hope is to fulfil two objectives, tentatively advanced. One is to trace the links between political geography and work in emotional geography, since grasping "the flux often actually entails a politics of 'fixing' - a politics which is, above all, operative in struggles about the construction of identities" (Geschiere \& Meyer, 1998: 605). Such struggles are never without reference to place and border politics (Davidson \& Milligan, 2004; Sparke, 2004, 2006). The other objective is indebted to the idea that the study of islands has "constituted a powerful approach within geographical tradition, yet paradoxically remains as peripheral to mainstream geographical thought as islands are commonly seen to be from continents" (Tsai \& Clark, 2003: 187). My aim is to place islands - and indeed one island - at the centre of the frame of analysis. Thus, a focus on one case, the island state of Tasmania, Australia, reflects a commitment to the idea that specific and localized studies are needed to 'fix' or ground the many that exist of 'globalization from above'.

\section{Of island geographies}

... small islands are special because their 'geographical precision' facilitates a (unique) sense of place (Baldacchino, 2005: 35).

Islands are varied spaces and polities, and generalisations about them must be made cautiously. Nevertheless, they provide lessons about the resourcefulness of jurisdiction that are 
transferable to "development problems of small societies in a whole variety of geographical, historical, political, economic and cultural circumstances" (Baldacchino \& Milne, 2000: 3). Among those problems is the risk that hostilities internal to such societies but not necessarily generated in them will escalate when political practices are used to prop up particular hegemonies and certain development futures. Debates about such futures are sometimes highly combative on islands, their peoples in conflict with outsiders or each other about how development might proceed, and how resources might be used and to what ends.

In positing the importance of an analytics of government, a political fixing, at least one theorist of governmentality gestures to the promise of thinking and acting in new ways; of rendering "practices of government problematic ... to reveal domination as a contingent, historical product, and hence to be questioned" (Dean, 1999: 38). In cases of deep division over development futures on islands, might islandness be productively used to shift attention from antagonistic to agonistic democratic practices? In posing this question, I am also indebted to Chantal Mouffe (2000: 17-19), who observes that the:

frontier between the social and the political is essentially unstable and requires constant displacements and renegotiations between social agents ... Things could always be otherwise and therefore every order is predicated on the exclusion of other possibilities ... As far as collective identities are concerned ... the 'they' represents the condition of possibility of the 'we', its 'constitutive outside' ... this is a crucial point because it allows us to envisage the possibility of different types of welthey relations according to the way the 'they' is constructed (emphasis added).

Over 550 million people live among 43 island nations, and many others live on sub-national islands of continental nation-states (Baldacchino, 2006). In an age of hyper-mobility, islands provide spatial and temporal limits, and foster strong sense of identity. As Françoise Péron (2004: 330) notes, islandness engenders closeness, solidarity, scrutiny, and capacities to accommodate and be tactful. There is:

a real art de vivre, sharing an ethos that is both private and communal... Island communities are also characterised by subtle internal divisions between inhabitants... Factions are formed because of differences of opinion about an issue concerning the island, but the political wind can change quickly and groups could then be realigned. Island life is never dull.

Economic globalization and ecological modernization are central metanarratives underpinning such alignments and realignments.

Not without qualification, it is accepted that economic globalization enables 'economy' to be enacted at various scales (Amin, 2002; Callon, 2002; Castree, 2002; Murdoch, 2000; Van Loon, 2000). It is informed by globally calculating norms, ideologies, values and allegiances. It needs and engages with the particularities of place and socio-spatial relations in and between places and, while also producing and influencing them, is implicated in the annihilation of those particularities. It gives effect to increased and accelerated flows of transactions, capital, resources, goods and services, ideas, people or communications (Conley, 2002; Fulcher, 2000; Geschiere \& Meyer, 1998; Held, McGrew, Goldblatt, \& Perraton, 1999). These flows are unevenly distributed, with varying consequences (Bosman, 1999; Gibbs, 2000; Gibbs \& Jonas, 2000; Hocking, 1999). For example, there is little doubt that 'isolated' and economically 'marginal' islands may be disadvantaged in development terms (Armstrong \& Read, 2003). Those who govern them may seek to maximize their economic returns in unsustainable ways, among them the 
extraction of slow-renewable and non-renewable resources from land and water - fish stocks, forests and mineral deposits not least among them.

Worldwide, the effects of economic globalization are witness to the growth of alternative movements (Cabus, 2001; Hocking, 1999; Starr \& Adams, 2003; Swyngedouw, 2000). Their members have been suspicious about sustainable development as one manifestation of ecological modernization - the idea that it is possible to maintain rates of economic growth and protect the environment via technological advances (Buttel, 2003; Higgott, 2000; Rutherford, 1999; Salskov-Iversen, Hansen, \& Bislev, 2000; Yeates, 2002; York \& Rosa, 2003). Ecological modernization has been criticized for its capacity to perpetuate the "domination and destruction of the environment and the promotion of less democratic forms of government, foregrounding modernity's industrial and technocratic discourses over its more recent, resistant and critical ecological components" (Christoff, 1996: 497). Yet, rhetorical and material investments in ecological modernization are apparent among island peoples. Witness the creation of the Small Island Developing States (SIDS) Unit in the United Nations, the formulation of the 1994 Barbados Plan of Action for SIDS and its reaffirmation in the 2005 Mauritius Declaration (Ambassador \& Koonjul, 2004; United Nations, 2004). The last of these underscored how support for sustainable development is viewed as important on islands because such places and their peoples are thought to experience pronounced ecological, social and economic vulnerabilities (Briguglio, 1999; King \& Connell, 1999; Nunn, 2004; Royle, 2001). By the same token, islands have also been described as places in which resourcefulness and innovation are hallmark traits (Baldacchino, 2004b; Briguglio, Cordina, \& Kisanga, 2006; Crowards, 2004). Studies of island vulnerability and resilience, while valuable, are also largely focused on nation-states - and SIDS in particular (Baldacchino, 2004a, 2005; Stratford, 2006b). Empirical studies of subnational island places and their political and emotional geographies are warranted if scholars are to better understand how islandness might be a resource in governing for development futures that are agonistically framed and conducive to the protection of place.

\section{A politics of fixing}

The very boundedness of islands makes them different. Physical boundedness conduces to psychological distinctiveness, because it promotes clearer, "bounded" identities. It also conduces to low dynamism, to social and political conservativism (Hay, 2003: 203).

So what of Tasmania? Significant moral forces are at play on this island in the roaring forties of the Southern Ocean - and they clash in the arena formed by deep antagonism between conservation and development agendas. In Tasmania, among the most pronounced of these conflicts has been a failure to challenge statist developmentalism, in relation to resource extraction and forestry in particular. Ken Walker (1999) defines statist developmentalism as the tendency to minimize or belittle environmental considerations and constraints, with the result that development is subsidized by the unsustainable use of resources over the medium to long term. In Australia, ${ }^{1}$ statist

\footnotetext{
${ }^{1}$ Australia comprises six States, two Territories and several island dependencies. Each State and Territory has powers secured in the Commonwealth Constitution Act, 1901 (Australian Government. Federal-State Relations Committee, 1997; Brown, 2004; Searle, 2002; Stratford, 2006a). Together and in competition, each engages in trade and development to reap the real and apparent benefits of economic globalization. Each depends on the Australian Government and each profits via a system of equalization to manage imbalances between core and periphery (Brown, 2004; Mathews, 1977; Stevens, 1977). Tasmania's reliance on the Commonwealth has been marked (Australian Government. Commonwealth Grants Commission, 2005; Mathews; Searle, 2002).
} 
developmentalism has been underpinned by welfare and marketization strategies, including those informed by ecological modernization and the specific discourses of sustainable development. Walker (1999) maintains that this regime is nowhere more marked than in Tasmania, where its effects have been highly divisive.

Approximately $250 \mathrm{~km}$ south of the Australian mainland off the south coast of the State of Victoria, Tasmania is the smallest and most economically peripheral member in the federation. Its people have confronted substantial tests of statist development over the 200 years since British colonization: depressions in the 1890s and 1930s, several recessions, and ongoing dependency on forestry, fishing, mining and agricultural production, each at the mercy of global market shifts. For much of the 20th century, Tasmania's economy was underpinned by hydro-industrialization, agriculture and resource extraction and, like islanders and sub-national populations elsewhere, Tasmanians have exhibited highly developed capacities to seek and find significant international markets for various goods (Baldacchino, 2006; Mingus, 2003). Of note, Tasmania was the birthplace of the world's first Green political party - the United Tasmania Group - which formed in March 1972 as a result of protests over the damming of a pristine lacustrine wilderness at Lake Pedder in the State's southwest. ${ }^{2}$

Conflicts over conservation and development emerged again over the period from 1989 to 1994 when the Tasmanian State Government, led by Premier Michael Field, confronted a fiscal crisis and was subject to intense local pressures to embrace the new international rhetoric of sustainable development as it had been conceived in the Brundtland Report (World Commission on Environment and Development, 1987) and gained momentum via Australian Government strategies for ecological sustainable development. ${ }^{3}$ In retrospect, the period was characterized by significant reforms to fiscal and resource management and planning, and entrenched fiefdoms based on access to resources were rattled but not necessarily overturned.

During that period of crisis, it is arguable that those who govern failed to notice how islandness might have been a resource in fiscal and policy reform. Opportunities for change are limited until we notice how failing to notice shapes our thoughts and deeds (Laing, 1972). In Tasmania, this failure to notice may derive from the fact that two narratives have dominated debate about the State's development trajectory since the mid 1960s. First, some argue that Tasmania's status as small, remote and peripheral makes it vulnerable, and they suggest that its comparative advantages in resource-extractive industries should be maximized. Second, some argue that the very same characteristics of size, isolation and marginality make Tasmania resilient against the homogenising effects of economic globalization, and they maintain that the island's comparative advantages should be in eco-tourism, smart technologies and a green political economy. Given these polarities it is not surprising that resident poet and scholar Peter

\footnotetext{
${ }^{2}$ Lake Pedder was a particularly significant lake in Tasmania's southwest, renowned for its pink quartzite beach. Dammed by the Hydro Electric Commission in the 1970s for cheap energy, from the late 1960s it was the focus of international protests against major infrastructure projects in wilderness areas and, for some, its destruction marked the beginnings of the international Green movement.

${ }^{3}$ The World Commission on Environment and Development had published the highly influential book, Our Common Future, only 2 years before the Field Government's election (World Commission on Environment and Development, 1987, 43). The then Prime Minister Hawke's Statement on the Environment was also published in 1989, committing Australia to nationwide activities on ecologically sustainable development in the lead-up to the 1992 United Nations Conference on Environment and Development, held in Rio de Janeiro. In 1992, the Australian Federal Government also introduced both the National Strategy on Ecologically Sustainable Development and the Intergovernmental Agreement on the Environment among Federal, state and local governments (Australian Government, 1991; Australian Government. Department of Environment and Heritage, 1992) - its chief committee being chaired by a senior Tasmanian public servant during that time.
} 
Hay (2000) describes Tasmania as a strange and verdant island with a strange and verdant politics. Expatriate writer Natasha Cica (2005) goes further, calling it a place of sentimental tribalism and internecine feuding.

In 1989, Tasmania's right-wing Liberal Government was forced from power and what became known as the 'Tasmanian Parliamentary Accord' Government was formed between the left-wing Australian Labor Party (ALP) and five Greens. It was quickly established that the State was near bankruptcy, prompting the development of a set of challenging fiscal reforms to government structures and systems intended to make Tasmania nationally and internationally competitive, and raze its reputation as the inward-looking mendicant of the federation. Known and hereafter referred to as the 'fiscal strategies', they have remained and evolved since 1989 (Parliament of Tasmania, 2001, 2002, 2004). Yet, by 1991 the Accord had collapsed over disagreements related to the development of resource-extractive industries in general and forestry in particular (Sandford, 1993), and the ALP went on to govern in minority until it was replaced by the Liberals from 1992 to 1998, when Labor was returned - a position it has maintained to the present. However, before they left the Accord, the Greens demanded and gained support for the creation of a novel Resource Management and Planning System (RMPS) that was then carried forward during Labor's minority government and enacted, in the main, by the Liberals in 1993/1994.

In September and October 2004, I spoke with key political and bureaucratic change-agents of Tasmania's fiscal strategies and RMPS in audio-taped semi-structured interviews of approximately 90 min' duration. Despite the closeness that island living may entail, all but three respondents were not known to me before interviews were conducted, and all were identified using criterion and chain selection methods. They needed to have had key involvement in the reforms of the day and/or their subsequent implementation, and high levels of seniority and capacity for decision-making at the time. Four respondents were politicians in the original Accord Government and 14 were senior public servants who worked (then or thereafter) in close association with the elected representatives. Provision of further details about respondents is not possible without breaching confidentiality and anonymity as required by Australian protocols on the ethical conduct of research. All are highly qualified individuals and our conversations were penetrating and provocative. Respondents were asked to think about the legacy of the fiscal strategies and RMPS; reflect on how these gave effect to or were informed by Tasmania's status as both a sub-national jurisdiction of Australia and an island; and ponder the State's political, economic and environmental position then and now. These areas of discussion allowed me to speculate about a number of issues under scrutiny as part of a 3-year research project, and to consider how an island affect might have prompted more productive tactics of government in a time of fiscal crisis, social upheaval and environmental discord.

Interviews were transcribed and sent to respondents to check over the period to June 2005. Once returned, each was read and reread several times and closely analysed for common and disparate ideas about four basic themes: the fiscal strategies, the RMPS, and Tasmania's status as a sub-national jurisdiction and an island; these themes have guided the structure of the rest of the paper. Transcripts were also refracted back through primary and secondary literatures to form interpretive and reflexive arguments, and in this sense the analysis is discursive and abductive (Fairclough, Jessop, \& Sayer, 2002; Hastings, 1999; Mason, 2004), reasoning from a set of 'accepted facts' reported to me about fiscal and policy reforms to a set of explanations generated by me that seems best to account for what has been observed - namely a fascinating disjuncture between political and emotional geographies on which I elaborate below. The 'lag' of remembering across 13 years from the advent of reforms posed little problem for any of the 
respondents, all of whom felt they remembered the period and its aftermath very clearly, and most of whom remain engaged in political and policy life. In this respect, it is useful to note that their narratives were corroborated by each other and by relevant primary literature. Nevertheless, there is no intention, here, to represent the views articulated as 'pure' memories of times past. Indeed, it is inevitable that what was shared with me was also coloured by more than a decade of engagement in political, bureaucratic and island life; reminiscences are complex interpretations affected by time and experience in place.

Next, drawing on respondents' own words in italics, I first describe how they view the legacy of the fiscal strategies and reforms to resource management and planning, and then examine the salience of islandness in the conduct of government, ${ }^{4}$ before asking what is at stake here?

\section{Considering the legacy of the fiscal strategies and RMPS}

One needs to start ... a long way back. This island has always had a population that has been spoilt and that's a product of the extraordinary dispersion of the population across the State; the development of regional and community loyalties, jealousies, competition ...

From 1989 to 1994, first Labor and then Liberal Tasmanian governments were engaged in a thorough overhaul of fiscal policies to combat a debt crisis in public finances that involved the wholesale restructure of the public service in Tasmania (Parliament of Tasmania, 1989, 1990, 1991, 1992, 1993). When asked what motivated the reform, one participant said that it was desperation ... I've looked back on it and asked were there alternatives and there weren't.

By May 1989, the political terrain in Tasmania was deeply fractured. Fifty-four State government departments, something in excess of 250 statutory bodies, and 47 local governments served a population under 460,000 people. Because of Tasmania's Hare Clark system ${ }^{5}$ of elections:

Politicians ... [are] very close to small communities of people [and that] enables a small bloc of electors to re-elect or dismiss a local member ... [so over time] governments shied away from ... decision-making that would prove contentious ... [and] transferred power and authority [to authorities, commissions and boards] ... It meant that gradually government lost control of its own infrastructure and the directions of development.

Over most of the 20th century, Tasmania's economic well-being had been marginal (Nixon, 1997). Every time Australia sneezed we caught a cold and when Australia got a cold, Tasmania got pneumonia. We were the first into recession and the last out. Unemployment levels were high; members of the island's entrepreneurial and intellectual classes were migrating from the island, as were many 19-30 years of age. There was growing disinvestment from industrial manufacturing and some forms of agriculture, and capital investment in resource-extractive economic activities was highly vulnerable to global market fluctuations. In short, Tasmania was increasingly indebted to others. In the words of one participant, the State Government began to use its:

statutory authorities as ... money-laundering machines. You would impose a significant tax or levy on, for example, the Forestry Commission ... and Government would leave

\footnotetext{
${ }^{4}$ In a forthcoming paper in preparation, I explore how a stratified sample of Tasmanian householders aged 25 years and above perceive Tasmania as distinctive from mainland states. Preliminary analysis suggests that, overwhelmingly, islandness (expressed as avatars of island such as isolation) is viewed as a tremendously valuable resource to be protected from influences that will render Tasmania "like everywhere else".

5 On the Hare Clark System see (Tasmanian Electoral Office, 2004).
} 
the Forestry Commission to borrow money because it was outside the guidelines and existing arrangements. So it would borrow and increase its debt and the State would have money to ... do something [in one little town or other] ... to get the forty six votes needed to get the party's candidate across the line at the next election.

Before May 1989, members of the ALP in Tasmania have been working on a 'transition to power' strategy in anticipation of the Liberals losing the election for what was described to me as comprehensive incompetence. Shortly after he came to office that month, the Labor Premier, Michael Field, instigated an assessment of Tasmania's finances. One participant recalled that Field:

couldn't believe what he was given by Treasury. He had it checked ... the Trade Unions were invited to appoint their own people to go through the books, the Chamber of Commerce [too]. They all came to the same conclusion - the State was bankrupt ...

In the first 3 weeks of Field's term in office, a select team began to work on a major review of public service structures. The debt crisis deeply affected how that review progressed and, in July 1989, Field announced a reduction from 54 to 18 government departments, and a major overhaul of the structure and function of statutory bodies. Simultaneously, discussions were being held with the Australian Government about the possibility of Tasmania losing its position as a State if it were forced to renege on its debts.

Various strategies were developed to deal with the debt crisis. The size of the public service was reduced by nearly a third in Field's first year. An AU\$200 million loan was negotiated with the Australian Government on condition that it was used to pay redundancies. The Field Government then developed a long-term program to address debt (Parliament of Tasmania, 1989; Tasmania. Department of Treasury and Finance, 1989). One participant described the tactics involved:

live within your means in terms of the capital budget and use your surplus to pay off debt ... re-engineer all government business enterprises and trading enterprises [to be] ... accountable for discharging their accrued debt ... fully fund superannuation of public servants ... reduce the annual interest bill to accelerate the debt repayment program ... reinvest some money into your infrastructure ... for three years we did not have a single cent.

In that period of absolute fiscal inflexibility the advent of the RMPS is noteworthy, although without pressure from its Accord partners I was told that the Field Government may not as readily have prioritised the System's creation even though Tasmanians were reeling from the effects of significant and internationally reported protests over development. These had commenced before and continued after the flooding for hydro-electricity of Lake Pedder, and included protests over proposals to construct the Gordon-below-Franklin dam in the southwest, build a paper and pulp Mill at Wesley Vale in the north, and maintain the logging of old-growth forests (Bates, 1994; Crowley, 1994; Davidson, 1995; Penman, 1993; Tighe, 1987; Tsamenyi \& Bedding, 1988). So, as part of their response to the imperative to restructure the Greens had insisted that the Accord should enshrine an international agenda for ecologically sustainable development in locally appropriate ways; indeed, the viability of the Government depended on it.

The RMPS resulted in the creation of a system of core and adjunct legislation for resource management and planning based on internationally agreed principles of sustainable development 
enshrined in schedules to all acts in the System. ${ }^{6}$ The original legislation included the Land Use Planning and Approvals Act (1993), Environmental Management and Pollution Control Act (1993), State Policies and Projects Act (1993) and disputes (Resource Planning and Appeals Tribunal Act, 1993). Asked how the System emerged during a period of fiscal crisis, some respondents referred to the influence of sustainable development, observing that it was about international thinking. We wanted to put Tasmania at the forefront with significant legislation. It was a big deal for us and deliberately intended. The influence of New Zealand's pioneering Resource Act 1990, was also apparent (McLean, 1992) but, at the same time,

the New Zealand legislation was considered too ambitious ... for Tasmania, and it was decided to move reform in bite size bits, because it was well known that resource extractive industries were protected sites of domination.

I was told that too radical a System would risk the reform process which, in certain quarters, was being interpreted as antagonistic to market forces and development. Since hostilities in small and sharply bounded spaces such as islands can be especially problematic for those who live and work on them, it may be that bureaucrats in particular were being careful to avoid the inscription of 'we/they identifications' (see Mouffe, 2000). The challenge, then, was to provide a framework that politicians would be willing to adopt, and avoid a political backlash among those with entrenched interests in resource-extractive industries, property development and other apparatus of ecological modernization. Yet despite being an advance over the traditional system, three key resource-extractive activities - marine farming, forestry and mining exploration - were finally exempt from the RMPS by the Liberal Government which came to power in 1992. I was told that to get the legislation through ... Parliament ... we [couldn't] ... die in a ditch [and make the System] too comprehensive too early on because that would have been the death of us. I was also told that the objectives of the RMPS were articulated in the middle of the night and then embodied in the Acts, one participant describing this feat as impressive given fiscal constraints. Another reflected on his abiding disappointment that forestry remained outside the RMPS, observing that it was equivalent to putting the poacher in charge of chicken coup. For many respondents, such an assessment will hold true until forestry is brought into the System.

\section{Considering questions of islandness}

[Studies of government] seek to interrogate the problems and problematisations through which 'being' has been shaped in a thinkable and manageable form, the sites and locales where these problems formed and the authorities responsible for enunciating upon them, the techniques and devices invented, the modes of authority and subjectification engendered, and the telos of ambitions and strategies (Rose, 2000: 22).

\footnotetext{
${ }^{6}$ In Schedule 1(1), the principles of the RMPS are to promote sustainable development and maintain genetic diversity; provide for the fair, orderly and sustainable use and development of air, land and water; encourage public involvement in resource management and planning; facilitate economic development in accordance with these objectives; and promote the sharing of responsibility for resource management and planning among different spheres of government, the community and industry. In Schedule 1(2), the objectives of the planning process are sound strategic planning and coordinated action by State and local governments; planning instruments to set objectives, policies and controls for the use, development and protection of land; methods to consider and provide for explicit consideration of social and economic effects flowing from the development and use of land; and planning and policy easily integrated with environmental, social, economic, conservation and resource management policies at State, regional and municipal levels.
} 
I now want to examine how respondents understood the significance of Tasmania's subnational and island status in the conduct of government. Three narratives emerged from our conversations. The first was that Tasmania's sub-national status and not its island status has been key. The second was that internal divisiveness has been the primary influence on decision-making and reform. A third and more complex argument was that island and sub-national status and internal division each informs the conduct of government. Last, almost all respondents suggested that Tasmania's islandness matters to them as private citizens but that such affective matters had no place in government.

(a) Not island but sub-national status: Tasmania exhibits many local manifestations of economic globalization and ecological modernization. When asked to comment on these forces in the context of Tasmania's sub-national and island status, respondents emphasized the importance of sub-nationalism. They attributed the State's vulnerabilities to its size, the characteristics of its resource base, its colonial and industrial histories, low levels of population growth, and regional and decentralized structure compared to mainland Australia (where urban primacy is pronounced). The State's smallness and marginal status relative to other sub-national jurisdictions in the federation were emphasized, and its island status was viewed as merely coincidental:

no concept of islandness informed our work at the time. We were a small player in a federal system ... [and] we did think more about the negatives ... of smallness. Certainly we did not conceptualize the RMPS in terms of islands, but rather we were aware of the State's vulnerability, and especially its fiscal vulnerability.

Others focused on the idea that Tasmanians exhibit both independence and innovation because we' re small. We have public sector innovation because of our size ... and a lot less 'churn'.

(b) Not islandness but internal division: A number of respondents suggested that a perpetual and disproportionate influence of resource-extractive industries on government in Tasmania might explain the failure of successive administrations to move from highly fragmented, dependent and localized systems of governance to those which are more fully integrated and less internally competitive. Harnessing capacity is integral to that task, and most respondents suggested that such capacity has yet to be fully expressed in Tasmania because of symbolic and material fissures internal to the island: fissures based on antagonistic identifications of friend/enemy that diminish a collective capacity for democratic pluralism (Mouffe, 2000). One participant did suggest that Tasmania does integration better than many because it is smaller. Here, at least, senior and middle management talk to one another more than in other places. But others demurred, one observing that integration is difficult to implement and not well understood politically, and our governance structures foster this. Another referred to the lack of integration in resource management, observing that government and private enterprise could pursue economic gain with no more than rhetorical concessions to sustainable development, suggesting that you don't get [a say over] resource allocation ... So what areas go to private forest and what areas of water get allocated to the marine farming planning - you don't go there.

(c) Sub-nationalism and internal division and, yes, also islandness: All the respondents acknowledged that the apparent disabilities of island status - smallness and isolation in particular - concerned most policy actors. One observed that, in general terms island economies are more susceptible to fluctuations in the international economy; their people tend to 
become more resistant to change, more insular; it's an island phenomenon. Another removed the physical specificities of island form and reduced island status to an avatar for isolation:

we are simply less well integrated into the national economy... Western Australia [a mainland jurisdiction separated from 'core' states by thousands of kilometres of arid land and desert] is an 'island' but its vast resources offset the need for supplementation and it has huge capacity to raise revenue.

Only three respondents suggested that Tasmania's island status explicitly informed their work during the period between 1989 and 1994. It is perhaps noteworthy that they were central players in the creation of the RMPS and in national discussions about sustainable development, and appear to have had a pronounced appreciation of the importance of island status to resource management and planning. One recalled

a very interesting discussion where we actually said, well hang on, this is a plus - in an environmentally sustainable development sense, we have this wonderful quarantine barrier around us. We're an entity; we don't have any sort of cross-border issues. It gives us a special identity and we ought to be thinking about what we can make out of the community that's special and having a special system around environment and planning and land management.

For these three respondents, isolation, scale and size were connected in positive and empowering ways with Tasmania's island status and with strong sense of identity in place as a governmental resource, etched by the presence of the Bass Strait:

if Bass Strait had not been there, there was no way that this State would have been selfgoverning ... Bass Strait really does count.

(d) Islandness belongs outside government - or does it? The three respondents who made explicit connections between development futures and islandness had been central to the creation of the RMPS rather than the fiscal reforms. For them the ramifications of deep and ongoing divisions over resource extraction were problems of both formal political and policy processes and of place-based identity and, for one, those divisions were redolent of deficits in Tasmania's moral economy. Forestry was seen to be especially problematic - as beyond conversation. I was told by one of the three that the reason Tasmania is in such a state about forestry ... is because there's no independent body making decisions about [it and] ... the issues with the greatest angst are those where we haven't applied ... principles of civic participation and the democratization of decision-making that were available through the RMPS. He felt that public participation in State political processes on resource management and planning had been crucial in protecting the island's unique and world-significant qualities. Nevertheless, he also questioned whether those processes were sufficiently robust and widespread given the limitations that had been built into the RMPS in order to guarantee resource security. Such manoeuvres exemplify the major political parties' almost indistinguishable ideological commitments to the global market economy, to upholding the gloss of ecological modernization, and to adversarial if not antagonistic modes of government.

Thus, to all but a minority, Tasmania's island status was coincidental in the conduct of government during the period of reform. However, and here I return to the apparent disjuncture 
between political and emotional geographies, there existed an almost universal perception among respondents of islandness as vital to Tasmanians' sense of identity in place. It is paradoxical, then, that respondents sought to distance from the conduct of government particular kinds of affect such as the personal value they placed on Tasmanians' island identifications. Might this seeming 'disconnect' partly explain how and why Tasmanians remain committed to (indeed apparently dependent on) statist developmentalism and yet are socially and culturally defensive of their island place and sense of identity?

In trying to understand this apparent disjuncture I return to Mouffe, who argues that antagonism produces friend/enemy relations predicated on the assumption of there being no common ground. In circumstances of inevitable difference, she appeals to the careful constitution of agonistic we/ they relations. In this light, might islandness as an affect, an emotional geography, be usefully deployed in the work of building new relations such that adversaries acknowledge the absence of rational solutions to their conflicts, but do not constitute each other as enemies? "This means that, while in conflict, they see themselves as belonging to the same political association, as sharing a common symbolic space within which the conflict takes place" (Mouffe, 2005: 20, emphasis added). I do not want to suggest that Tasmanians - any more than other peoples - should deny their disagreements or attempt to produce a gloss of consensual harmony. But a denial of islandness as productive of both real and symbolic common space suggests opportunities foregone to recraft political practices for agonistic ends. Tasmania has long been dominated by rational but sometimes highly unreasonable approaches to government. That domination has been sharply etched as political representatives and policy makers seek to position the island State as part of the global market economy, informed by the optimism of ecological modernization and adhering to the rhetorical framework of sustainable development (Christoff, 1996; Dean, 1999). A reluctance or inability to deploy islandness as an ontological resource without cynicism or instrumental calculation also suggests that other forces are at play here, forces for which Tasmania, as unique island place, means little and is rendered absent. In such a climate, there may be manifold opportunities to rethink the telos of ambitions and strategies that inform the conduct of government as Rose (2000) suggests. There may be opportunities to confront the profoundly problematic political geographies of statist developmentalism and an island divided, and to work with purpose for the constitution of meaningful democratic debate and public policy informed by sensitivity to the emotional geographies of those involved.

\section{Conclusions}

I began this paper by suggesting that islands are constitutive of strong place-based identifications - emotional geographies that may be described as islandness; something that is affective and ontological (Cica, 2005; Deloughrey, 2004; Hay, 2006). I proposed that island governments, national and sub-national alike, are engaged in processes of economic globalization and ecological modernization in ways that differ (at least in part) from continental counterparts. I also advanced the idea that islandness moves people to value the special qualities of islands and protect them, often in response to globalization and modernization. Nevertheless, I also suggested that, in the conduct of government and in the production of various political geographies, those who govern on islands may be motivated or compelled to ignore, hide or 'fail to notice' the utility - indeed the ontological import - of islandness in their decision-making processes, especially where the imperatives of (economic) development are prioritised in the polity and generate internal conflicts over possible futures. Given Geschiere and Meyer's (1998) commentary on the value of 'fixing' the analytic gaze on the construction of identities 
in order to appreciate the flux of globalization, and also given Tsai and Clark's (2003) observations on the marginal place of island studies in mainstream geographical thought, I then sought to focus on struggles over development on one island. My intention has been to understand what might be the implications of a disjuncture between the emotional and political geographies that can be mapped among those who govern there during a time of fiscal crisis and policy reform, and thus to make contributions to scholarship on political geography's microscalar connections to geographies of affect and emotion.

What insights have been derived from that work? Tasmania, is the only sub-national island state in the Australian federation; in past times typified as the nation's basket-case, economically dependent and socially backward, and reliant upon resource-extractive industries that create significant divisions about development futures despite widespread and deep-seated attachment to the island as place. Such stereotypes have, I would suggest, prompted a culture in the conduct of government that tends to the denial of islandness as an ontological resource. In the final analysis, most of those to whom I spoke valued Tasmania as island when they could distinguish it as a powerful source of identification outside the operation of government policy as they saw and crafted it. With few exceptions, they suggested that islandness did not inform Tasmanian policy debates during a period of significant economic, social and environmental discord, except as a container for all that was wrong about Tasmania's peripheral status relative to the Australian mainland. Has a failure to notice foundational emotional geographies of islandness and to foreground an ontological presencing of islandness in the conduct of government resulted in a failure to utilize the immense resourcefulness that such ontologies could provide? Has that, in turn, resulted in Tasmania becoming part of the 'everywhere the same' as Péron (2004) or Cica (2005) or Hay (2006) would suggest? The continued exemption of particular resource-extractive industries from full public scrutiny might suggest so, and key policy actors seemed to feel so even if they cannot say as much in public - an affect that perhaps reflects their powerful attachment to place and the tensions inherent in subordinating those attachments in the conduct of government.

\section{Acknowledgments}

Research informing the work reported here was sustained by an Australian Research Council Discovery Grant (DP0342802) funded between 2003 and 2005. I am indebted to all of the respondents in the research, who gave most generously of their time, and were candid and thoughtful in their responses to my questions. Thanks are due to Stewart Williams, Aidan Davison, Carol Farbotko, Andrew Harwood, three anonymous reviewers and very patient and helpful editors for their insightful comments and feedback on this manuscript.

\section{References}

Ambassador, H. E., \& Koonjul, J. (2004). The special case of Small Island Developing States for sustainable development. Natural Resources Forum, 28, 155-156.

Amin, A. (2002). Spatialities of globalisation. Environment and Planning A, 34, 385-399.

Armstrong, H. W., \& Read, R. (2003). The determinants of economic growth of small states. The Round Table, 368, 99-124.

Australian Government. (1991). Ecologically sustainable development working groups draft report executive summaries. Canberra: Australian Government Printing Service.

Australian Government. Commonwealth Grants Commission. (2005). Report on state revenue sharing relativities. Canberra: Commonwealth Grants Commission.

Australian Government. Department of Environment and Heritage. (1992). National strategy for ecologically sustainable development. Canberra: Australian Government. 
Australian Government. Federal-State Relations Committee. (1997). Report on Australian federalism: The role of the states. Melbourne: Parliament of Victoria.

Baldacchino, G. (2004a). Autonomous but not sovereign: a review of island sub-nationalism. Canadian Review of Studies in Nationalism, 31, 77-89.

Baldacchino, G. (2004b). The coming of age of island studies. Tijdschrift voor Economische en Sociale Geografie, 95 , $272-283$.

Baldacchino, G. (2005). The contribution of 'social capital' to economic growth: lessons from island jurisdictions. The Round Table, 94, 31-46.

Baldacchino, G. (2006). Personal communication: why island studies matters.

Baldacchino, G., \& Milne, D. (2000). Lessons from the political economy of small islands: The resourcefulness of jurisdiction. Basingstoke: Macmillan.

Bates, G. (1994). Land use planning reforms: Tasmania. Environment and Planning Law Journal, 11, $101-103$.

Bosman, M. M. (1999). The political rhetoric of corporate globalisation and the possibilities for counter-hegemonic projects. Space and Polity, 3, 125-152.

Briguglio, L. (1999). Editorial comment on the island studies series. In R. King, \& J. Connell (Eds.), Small worlds, global lives: Islands and migration. London/New York: Pinter.

Briguglio, L., Cordina, G., \& Kisanga, E. J. (2006). Building the economic resilience of small states. London/Malta: Formatek for the Commonwealth Secretariat.

Brown, A. J. (2004). One continent, two federalisms: rediscovering the original meanings of Australian federal ideas. Australian Journal of Political Science, 39, 485-504.

Buttel, F. H. (2003). Environmental sociology and the explanation of environmental reform. Organization and Environment, 16, 306-344.

Cabus, P. (2001). The meaning of local in a global economy: the "region's advocacy of local interests" as a necessary component of current global/local theories. European Planning Studies, 9, 1011-1029.

Callon, M. (2002). Technology, politics and the market: an interview with Michel Callon. Economy and Society, 31, 285-306.

Castree, N. (2002). Environmental issues: from policy to political economy. Progress in Human Geography, 26, $357-365$.

Christoff, P. (1996). Ecological modernisation, ecological modernities. Environmental Politics, 5, 476-500.

Cica, N. (2005). Turbo Tassie. Island, 101, 6-17.

Clark, E. (2004). The ballad dance of the Faeroese: island biocultural geography in an age of globalisation. Tijdschrift voor Economische en Sociale Geografie, 95, 284-297.

Conley, T. (2002). The state of globalisation and the globalisation of the state. Australian Journal of International Affairs, 56, 447-471.

Crowards, T. (2004). Identifying policy responses to vulnerability. Wise coastal practices for sustainable human development forum.

Crowley, C. M. (1994). Power and environmental policy: Tasmanian ecopolitics from Pedder to Wesley Vale. University of Tasmania.

Davidson, J. (1995). Sociopolitical transformation: the impact of the Tasmanian Greens. Environmentalism, public opinion and the media. Hobart: Tasmania.

Davidson, J., \& Milligan, C. (2004). Embodying emotion sensing space: introducing emotional geographies [Editorial]. Social and Cultural Geography, 5, 523-532.

Dean, M. (1999). Governmentality. Power and Rule in Modern Society. London: Sage Publications.

Deloughrey, E. (2004). Island ecologies and Caribbean literatures. Tijdschrift voor Economische en Sociale Geografie, 95, 298-310.

Fairclough, N., Jessop, B., \& Sayer, A. (2002). Critical realism and semiosis. Journal of Critical Realism, 5, 2-10.

Fulcher, J. (2000). Globalisation, the nation-state and global society. Sociological Review, 48, 522-543.

Geschiere, P., \& Meyer, B. (1998). Globalization and identity: dialectics of flow and closure. Development and Change, $29,601-615$.

Gibbs, D. (2000). Ecological modernisation, regional economic development and regional development agencies. Geoforum, 31, 9-19.

Gibbs, D., \& Jonas, A. E. G. (2000). Governance and regulation in local environmental policy: the utility of a regime approach. Geoforum, 31, 299-313.

Hache, J.-D. (1998). Towards a political approach to the island question. In G. Baldacchino, \& R. Greenwood (Eds.), Competing strategies of socio-economic development for small islands. Charlottetown, Prince Edward Island: Institute for Island Studies, University of Prince Edward Island. 
Hastings, A. (1999). Analysing power relations in partnerships: is there a role for discourse analysis? Urban Studies, 36 , 91-106.

Hay, P. (2000). Public lecture: The strange and verdant politics of a strange and verdant island. Charlottetown: Institute of Island Studies, University of Prince Edward Island.

Hay, P. (2003). That islanders speak, and others hear. Isle, 10, 203-205.

Hay, P. (2006). A phenomenology of islands. Island Studies Journal, 1, 19-42.

Held, D., McGrew, A., Goldblatt, D., \& Perraton, J. (1999). Globalization. Global Governance, 5, 483-496.

Higgott, R. (2000). Contested globalization: the changing context and normative challenges. Review of International Studies, 26, 131-153.

Hocking, B. (1999). Patrolling the 'frontier': globalization, localization and the 'actorness' of non-central governments. Regional and Federal Studies, 9, 17-39.

Holm, W. (2002). Eccentric islands: Travels real and imaginary. Minneapolis: Milkweed Editions.

King, R., \& Connell, J. (1999). Small worlds, global lives: Islands and migration. London/New York: Pinter.

Laing, R. D. (1972). Knots. New York: Random House.

Mason, J. (2004). Qualitative researching (2nd ed.). London: Sage Publications Ltd.

Mathews, R. (1977). Philosophical, political and economic conflicts in Australian federalism. Victoria, British Columbia: Institute of Public Administration of Canada.

Mathews, R. (no date). Fiscal equalisation in Australia: the methodology of the Grants Commission. Centre for Research on Federal Financial Relations, The Australian National University.

McLean, J. (1992). New Zealand's Resource Management Act 1991: process with purpose? Otago Law Journal, 7 , $538-555$.

Mingus, M. S. (2003). Transnationalism and subnational paradiplomacy: Is this perforated sovereignty or are democracy and civil society just reaching across borders? Presented at the 16th Annual Conference of the Public Administration Theory Network. Anchorage, Alaska.

Mouffe, C. (2000). The democratic paradox. London: Verso.

Mouffe, C. (2005). On the Political. New York: Routledge.

Murdoch, J. (2000). Networks - a new paradigm of rural development? Journal of Rural Studies, 16, 407-419.

Nixon, P. (1997). Commonwealth-State Inquiry into the Tasmanian Economy: Report to the Prime Minister of Australia and the Premier of Tasmania (The Nixon Report: Tasmania into the 21 st Century). Hobart: Tasmanian Government.

Nunn, P. (2004). Through a mist on the ocean: human understanding of island environments. Tijdschrift voor Economische en Sociale Geografie, 95, 311-325.

Parliament of Tasmania. (1989). Budget speech 1989-90. Hobart: The Government Printer.

Parliament of Tasmania. (1990). Budget speech 1990-91. Hobart: The Government Printer.

Parliament of Tasmania. (1991). Budget speech 1991-92. Hobart: The Government Printer.

Parliament of Tasmania. (1992). Budget speech 1992-93. Hobart: The Government Printer.

Parliament of Tasmania. (1993). Budget speech 1993-94. Hobart: The Government Printer.

Parliament of Tasmania. (2001). 2001-2002 Budget speech. 'Caring for communities, boosting business'. Hobart: The Government Printer.

Parliament of Tasmania. (2002). 2002-2003 Budget speech. 'Jobs, people, progress'. Hobart: The Government Printer. Parliament of Tasmania. (2004). 2004-2005 Budget speech. 'Investing in people'. Hobart: The Government Printer.

Penman, C. B. (1993). The Tasmanian Forest Industry - Resource Security and the Nature of State Obligations. Environmental and Planning Law Journal, 10, 239-250.

Péron, F. (2004). The contemporary lure of the island. Tijdschrift voor Economische en Sociale Geografie, 95 , $326-339$.

Rose, N. (2000). Community, citizenship and the third way. American Behavioral Scientist, 43, 1395-1411.

Royle, S. A. (2001). A geography of islands: small island insularity. London: Routledge.

Rutherford, P. (1999). Ecological modernization and environmental risk. In E. Darier (Ed.), Discourses of the environment. Oxford: Blackwell Publishing.

Salskov-Iversen, D., Hansen, H. K., \& Bislev, S. (2000). Governmentality, globalization, and local practice: transformations of a hegemonic discourse. Alternatives, 25, 183-222.

Sandford, R. (1993). The Salamanca Agreement. In M. Haward, \& P. Larmour (Eds.), The Tasmanian Parliamentary Accord and Public Policy 1989-92. Accommodating the new politics? Canberra: Federalism Research Centre, The Australian National University.

Searle, R. (2002). Federal fiscal relations in Australia - 2001. Torino: International Centre for Economic Research.

Sparke, M. (2004). Political geography: political geographies of globalization (1) - dominance. Progress in Human Geography, 28, 777-794. 
Sparke, M. (2006). Political geography: political geographies of globalization (2) - governance. Progress in Human Geography, 30, 357-372.

Starr, A., \& Adams, J. (2003). Anti-globalization: the global fight for local autonomy. New Political Science, 25 , $19-42$.

Stevens, R. M. (1977). Asymmetrical federalism: the federal principle and the survival of the small republic. Publius, 7 , 177-204.

Stratford, E. (2003). Flows and boundaries: small island discourses and the challenge of sustainability, community and local environments [Editorial]. Local Environment, 9, 541-560.

Stratford, E. (2006a). Isolation as disability and resource: considering sub-national island status in the constitution of the 'New Tasmania'. The Round Table: Commonwealth Journal of International Affairs 575-588.

Stratford, E. (2006b). Technologies of agency and performance: Tasmania together and the constitution of harmonious island identity. Geoforum, 37, 273-286.

Swyngedouw, E. (2000). Authoritarian governance, power, and the politics of rescaling. Environment and Planning D-Society and Space, 18, 63-76.

Tasmania. Department of Treasury and Finance. (1989). Budget overview. Hobart: The Government Printer.

Tasmanian Electoral Office. (2004). Tasmania's Hare-Clark Electoral System. Tasmanian Electoral Office.

Tighe, P. (1987). Environmental values, legalism and judicial rationality: the Tasmanian dam case and its broader political significance. Environmental and Planning Law Journal, 14, 134-143.

Tsai, H.-M., \& Clark, E. (2003). Nature-society interactions on islands: introduction. Geografiska Annaler, 85, $187-189$.

Tsamenyi, M. B., \& Bedding, J. (1988). The world heritage convention in the high court: a commentary on the Tasmanian forests case. Environmental and Planning Law Journal, 5, 232-242.

United Nations. (2004). International Meeting to Review the Implementation of the Programme of Action for the Sustainable Development of Small Island States. A/Conf207/L.6.

Van Loon, J. (2000). Organizational spaces and networks. Space and Culture, 4-5, 109-112.

Walker, K. J. (1999). Statist development in Australia. In K. Crowley, \& K. J. Walker (Eds.), Australian Environmental Policy 2. Studies in Decline and Devolution. Sydney: University of New South Wales Press.

World Commission on Environment and Development. (1987). Our common future. Melbourne, Oxford: World Commission on Environment and Development.

Yeates, N. (2002). Globalization and social policy: from global neoliberal hegemony to global political pluralism. Global Social Policy, 2, 69-91.

York, R., \& Rosa, E. A. (2003). Key challenges to ecological modernization theory. Institutional efficacy, case study evidence, units of analysis, and the pace of eco-efficiency. Organization and Environment, 16, 273-288. 